ISSN 0258-7122

Bangladesh J. Agril. Res. 38(4): 637-646, December 2013

\title{
POTATO (Solanum tuberosum L.) VARIETY DEVELOPMENT THROUGH HYBRIDIZATION: A NEW ERA IN BANGLADESH
}

\author{
B. C. KUNDU ${ }^{1}$, M.S. ISLAM ${ }^{2}$, M. A. KAWOCHAR ${ }^{2}$ AND M. H. RASHID ${ }^{3}$
}

\begin{abstract}
Systematic research on potato variety development has been in practice in Bangladesh since 1960, but until 2012, not a single variety was developed in this country through conventional breeding method, mainly due to the short day climatic factors which are not congenial for potato plants to flower. Due to the diversified efforts, TCRC scientists were able to make a breakthrough to overcome the climatic barriers. Flowering was induced in HYV potatoes and produce berries in the year 2000. After hybridization and continuous selection, five hybrid clones were placed in a RYT in 2010-11 from a batch of $502 \mathrm{~kg} \mathrm{~F}$ seedling tubers produced from 45 gram hybrid seeds of 2001-02. Based on the performances of SYT, AYT, RYT and on-farm trials, three varieties were released by the NSB in 2012 as BARI Alu-35, BARI Alu-36, and BARI Alu-37. Their genotype numbers are $4.5 \mathrm{~W}, 4.26 \mathrm{R}$, and 4.40 , their mean yields were 38.36, 33.82, and 34.88 t/ha in AYT, 44.01, 41.84, and 40.58 t/ha in RYT, and 38.87, 38.52, and $37.53 \mathrm{t} / \mathrm{ha}$ in on-farm trials, respectively.
\end{abstract}

Keywords: Potato, hybridization, Bangladesh.

\section{Introduction}

Potato (Solanum tuberosum L.) is one of the most promising crops in Bangladesh due to its high productivity, short duration, and wide adaptability. Although research and development of HYV potato was started regularly in 1960, its varietal improvement has only been limited to introduction and selection until the year 2000 (Rashid et al., 1987) due to the adverse climatic factors of Bangladesh. Potato plants do not flower under the short day conditions of Bangladesh. In the recent years, hybridization has been made possible at the TCRC after continuous efforts on variety selection under extended photoperiod and use of flower induction techniques (Rashid et al., 1990; Rashid et al., 1993; Rasul et al., 1994). Several treatments like extension of photoperiod, brick planting, stem girdling, grafting on tomato, and use of hormones, alone or in combination, have been found effective in inducing flowers and berry setting in potato (Clarke and Lombard, 1939; Patterson, 1953; Thijn, 1954; Zafar, 1955; Rashid et al., 1990; Rashid et al., 1993; Rasul et al., 1994).

Systematic hybridization was initiated in 1999-2000 (Rashid \& Hoque, 2009) and hybrid seeds are being produced and clones are being evaluated every year

${ }^{1}$ Senior Scientific Officer, Tuber Crops Research Centre (TCRC), Bangladesh Agricultural Research Institute (BARI), Gazipur, ${ }^{2}$ Scientific Officer, TCRC, BARI, Gazipur, ${ }^{3}$ Ex Director, BARI, Gazipur, Bangladesh. 
following systematic evaluation procedure (TCRC, 2001 to 2010; Rashid, 2004). The first batch of clonal hybrids were evaluated by the Technical Committee in 1911-12 and three varieties were released in 2012 (TCRC, 2012; Kundu and Kabir, 2012). These are the first potato varieties of Bangladesh. Through this procedure, new varieties will be coming up with desired qualities, and thus the dependency on imported varieties will reduce. The major objective of the hybridization process is to develop new varieties with high yield, good marketability, disease and insect tolerance/resistance, good keeping quality, and wider adaptability.

\section{Materials and Method}

Potato breeding following hybridization is a complex and lengthy procedure developed through trials and errors of 1980s and 1990s (Rashid, 1993). Even after several treatment combinations, maximum varieties, especially long day adapted European ones could not be induced flower under Bangladesh condition. To overcome all the problems, breeding facilities were developed both at Joydebpur and Debigonj. Hybridization was done in open field under extended photoperiod up to 11 pm every day with the help of High Pressure Sodium lights maintaining a minimum of 500 Lux at plant level starting from the emergence to senescence of plants. After flowering, hybridization is made in possible combinations. Seeds are sown in specially prepared beds after breaking dormancy of the true seeds. Following procedure is generally followed to develop a variety after hybridization:

\section{Procedure of variety development of potato through hybridization}

Seeds are sown at $10 \times 10 \mathrm{~cm}$ spacing on the seed beds under net house. Plants are harvested at 110 days. One tuber is selected per seedling. Only tubers of desired shape, size and color are selected.

Tubers are planted at wide spacing $(70 \times 40 \mathrm{~cm})$ under net house. Check varieties are planted in between two progenies. 5-10\% hills are selected based on yield, tuber size, shape and color. Each hill is bagged separately (8 to 10 tubers/bag)

Each bag (7 tubers) are planted in one row at 70 x $40 \mathrm{~cm}$ spacing under net house. Rows with desirable plants are marked at 60 DAP. At 90 1st year, $\mathrm{F}_{1} \mathrm{C}_{\mathrm{O}}$.
$2^{\text {nd }}$ year, $\mathrm{F}_{1} \mathrm{C}_{1} \quad$ (1st clonal gen.), single tuber bed.

$3^{\text {rd }}$ year, $\mathrm{F}_{1} \mathrm{C}_{2} \quad\left(2^{\text {nd }}\right.$ clonal gen.), Plant (single) row bed. 
DAP, all plants are harvested, data are recorded from five good plants. Good rows are selected based on size, shape, color and yield of tubers, and foliage type. Selected five hills are bulked for seed.

The above three generations are planted under net house<smiles>c1cc[cH-]c1</smiles>

In this generation ten tubers from each bag is planted under the net house for seed multiplication, the rest seeds are planted in one bed at $60 \times 40 \mathrm{~cm}$ spacing under open field (usually three rows of ten tubers each). First selection is based on the plant type and disease tolerance/resistance at 60 DAP, and final selection is done on yield and tuber qualities. All tubers of each clone are bulked except poor yielding plants. Two checks BARI Alu-7(Diamant) and BARI Alu-8 (Cardinal) are always maintained at same spacing..

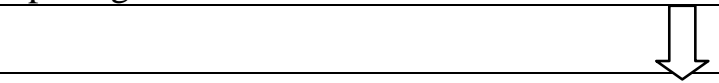

$4^{\text {th }}$ year, $\mathrm{F}_{1} \mathrm{C}_{3}$ ( $3^{\text {rd }}$ clonal gen.)

Single bed
In this generation similar methods are followed. Selected clones are planted for seed increase to conduct replicated yield trial in the next generation. Undesirable clones are rejected.

$5^{\text {th }}$ year, $\mathrm{F}_{1} \mathrm{C}_{4}$ ( $4^{\text {rd }}$ clonal gen.) Single bed

$6^{\text {th }}$ year, $\mathrm{F}_{1} \mathrm{C}_{5}$ (5th clonal gen.) PYT tuber yield and tuber qualities. Harvested seeds are bulked for seed.

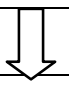

3 rows of 10 tubers each are planted in 3 replicated plots at six locations at $60 \times 25 \mathrm{~cm}$ spacing in open field. Two checks are used. Clones are selected based on selection criteria (score sheet). Harvested seeds are bulked for seed.<smiles>C1=C[C+]2CCC=1C2</smiles>

5 rows of 12 tubers each are planted in 3-4 replicated plots at six locations at $60 \times 25 \mathrm{~cm}$ spacing. Two checks are used. Clones are selected based on selection criteria (score 8th year, $\mathrm{F}_{1} \mathrm{C}_{7}$ (7th clonal gen.)

AYT 
sheet) and regional choice. Harvested seeds are bulked for seed.

Early variety, late planting, processing, storability, disease pressure, agronomic trials and participatory variety trials (PVS), etc. are done separately in this generation. Selection is based on all of the trials. A review meeting is done for selection of varieties to be placed in the RYT in the next season. PVS trial results, yield stability, farmers' preference, storability, etc. are considered during selection.

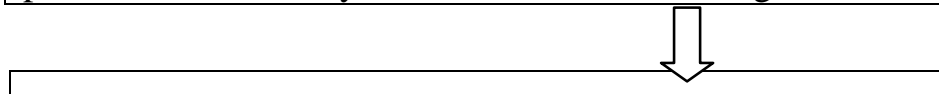

Regional yield trial (RYT) is done at $8^{\text {th }}$ or $9^{\text {th }}$ clonal generation.The trials are set up as per NSB requirement in each major agro-ecological region. At least six location means are required presently. One set of trial is conducted at BADC seed farm for their understanding. Net house materials are used. A variety is released by National Seed Board (NSB) on recommendation of the Technical Committee based on the results of the RYT and On-farm trial.

Six rows of 12 tubers each are planted in 3-4 replicated plots at least at six locations at $60 \times 25 \mathrm{~cm}$ spacing. Two checks are used. Two rows are harvested at 65 DAP and others are harvested at 90 DAP in presence of Regional Technical Committee of NSB.

On farm/participatory trial: With the same varieties at least two trials are set up at each of the six locations in farmers fields. The farmers grow the materials according to their own management but with the monitoring and supervision of the DAE officials and TCRC researchers. Data are recorded in presence of the Technical Committee at crop maturity.

\section{Results and Discussion}

The released three new varieties were selected out of 2001-02 crossed 45g true seeds in 20 combinations which produced $502 \mathrm{~kg}$ seedling tubers in 2002-03. Selected plants were grown in plant-rows out of which 400 lines were selected in 2003-04. In the next generation, 42 genotypes (single plots) were selected. In 2005-06, 32 genotypes were planted in replicated yield trial (PYT). In SYT, 18 clones were evaluated at two locations (2008-09). All of the generations' results 
were encouraging (TCRC, 2001 to 2010). Advanced yield trial was conducted with 11 clones at six locations in 2009-2010. The results are presented in Table 1.

Table 1. Performances of $F_{1} C_{6}$ clonal hybrids in AYT over six locations.

\begin{tabular}{|c|c|c|c|c|c|c|c|}
\hline \multirow{2}{*}{$\begin{array}{c}\text { Hybrid } \\
\text { clone/ } \\
\text { variety }\end{array}$} & \multicolumn{7}{|c|}{ Tuber yield (t/ha) at 90 DAP } \\
\hline & Joy. & Mun. & Bog. & Jam. & Jes. & Deb. & Mean \\
\hline 3.24 & $26.10 \mathrm{c}$ & 26.3 cde & 24.99 a-c & 33.50 e & 27.78 c & - & 27.73 \\
\hline 4.11 & $18.54 \mathrm{~d}$ & $22.00 \mathrm{e}$ & $10.78 \mathrm{~d}$ & $23.00 \mathrm{f}$ & $18.59 \mathrm{~d}$ & 45.33 b-e & 23.04 \\
\hline 4.15 & $25.20 \mathrm{C}$ & $36.80 \mathrm{a}$ & $24.35 \mathrm{a}-\mathrm{c}$ & $35.60 \mathrm{~cd}$ & 30.85 bc & 46.63 a-e & 33.24 \\
\hline $4.26(\mathrm{~W})$ & $33.07 \mathrm{~b}$ & 24.5 de & 22.92 bc & 34.60 de & 28.14 c & $47.31 \mathrm{a}-\mathrm{d}$ & 31.76 \\
\hline $4.26(\mathrm{R})$ & $22.97 \mathrm{~cd}$ & 27.9 b-e & $21.75 \mathrm{c}$ & $41.70 \mathrm{a}$ & $34.90 \mathrm{ab}$ & $53.70 \mathrm{ab}$ & 33.82 \\
\hline 4.27 & 29.65 bc & 32.50 abc & 28.51 a-c & $42.30 \mathrm{a}$ & $35.83 \mathrm{ab}$ & $55.18 \mathrm{a}$ & 37.33 \\
\hline 4.32 & $33.34 \mathrm{~b}$ & 33.20 abc & 23.05 bc & 39.50 b-e & 39.59 a & $54.98 \mathrm{a}$ & 37.28 \\
\hline 4.40 & 27.05 bc & $29.60 \mathrm{a}-\mathrm{d}$ & $31.94 \mathrm{ab}$ & $42.30 \mathrm{ab}$ & $36.30 \mathrm{ab}$ & $42.07 \mathrm{c}-\mathrm{f}$ & 34.88 \\
\hline $4.47(\mathrm{R})$ & $25.64 \mathrm{c}$ & $34.30 \mathrm{ab}$ & $27.96 \mathrm{a}-\mathrm{c}$ & 36.60 be & 33.24 abc & $52.63 \mathrm{ab}$ & 35.06 \\
\hline $4.5(W)$ & 41.08 a & $33.00 \mathrm{abc}$ & 30.00 a-c & $42.70 \mathrm{abc}$ & 31.30 bc & $52.08 \mathrm{ab}$ & 38.36 \\
\hline $4.5(\mathrm{R})$ & 27.58 bc & $33.00 \mathrm{abc}$ & $22.31 \mathrm{c}$ & 31.40 de & 33.05 abc & 50.55 abc & 32.98 \\
\hline $\begin{array}{l}\text { BARI Alu-7 } \\
\text { (Diamant) }\end{array}$ & 27.53 bc & $31.10 \mathrm{a}-\mathrm{d}$ & 32.89 a & $41.40 \mathrm{ab}$ & 31.39 bc & 44.41 b-e & 34.79 \\
\hline $\begin{array}{l}\text { BARI Alu-8 } \\
\text { (Cardinal) }\end{array}$ & $33.00 \mathrm{~b}$ & 27.90 b-e & 32.59 a & 29.50 e & $34.07 \mathrm{ab}$ & 46.18 a-e & 33.87 \\
\hline CV (\%) & 12.70 & 9.44 & 19.08 & 7.45 & 10.29 & 12.3 & - \\
\hline
\end{tabular}

Means followed by the same or no letter in the same column do not differ significantly each other at the $5 \%$ level by DMRT

AYT results showed that the clones 4.5W, 4.40, and 4.26R performed better in most of the stations. $4.5 \mathrm{~W}$ produced the highest mean yield (38.36 t/ha), followed by 4.40 (34.88 t/ha). 4.26R produced $33.82 \mathrm{t} / \mathrm{ha}$. This high yield in the $8^{\text {th }}$ generation is highly encouraging.

Similarly, in the RYT at six locations, $4.5 \mathrm{~W}$ produced the highest yield (44.01 t/ha), white $4.26 \mathrm{R}$ produced the $2^{\text {nd }}$ highest yield (41.84 t/ha), closely followed by $4.40(40.58 \mathrm{t} / \mathrm{ha})$. All these three were better than the checks (Table 3). Genotype $4.5 \mathrm{~W}$ also yielded highest at 65 days of harvesting (27.2 t/ha), 4.40 was the $2^{\text {nd }}$ highest (23.67), while $4.26 \mathrm{R}$ produced $20.9 \mathrm{t} / \mathrm{ha}$ (Table 2). The check varieties produced 24.34 and 23.13 t/ha. This indicated that these varieties are also early bulkers. 
Table 2. Performances of clonal potato hybrids for tuber yield at 65 DAP in RYT at six locations.

\begin{tabular}{l|c|c|c|c|c|c|c}
\hline \multirow{2}{*}{$\begin{array}{c}\text { Hybrid } \\
\text { Clone/Variety }\end{array}$} & \multicolumn{7}{c}{ Tuber yield (t/ha) at 65 DAP } \\
\cline { 2 - 8 } & Joy. & Bog. & Mun. & Jes. & Jam. & Deb. & Mean \\
\hline 4.15 & $18.43 \mathrm{a}$ & $13.67 \mathrm{~b}$ & $11.50 \mathrm{~b}$ & $20.56 \mathrm{~cd}$ & $25.00 \mathrm{c}$ & 23.56 & 18.79 \\
$4.26 \mathrm{R}$ & $19.58 \mathrm{a}$ & $16.33 \mathrm{ab}$ & $11.30 \mathrm{~b}$ & $24.00 \mathrm{bc}$ & $28.56 \mathrm{bc}$ & 25.65 & 20.90 \\
4.27 & $21.13 \mathrm{a}$ & $15.33 \mathrm{ab}$ & $10.30 \mathrm{~b}$ & $16.36 \mathrm{~d}$ & $28.93 \mathrm{bc}$ & 23.01 & 19.18 \\
4.40 & $21.79 \mathrm{a}$ & $16.33 \mathrm{ab}$ & $20.60 \mathrm{a}$ & $23.03 \mathrm{c}$ & $30.72 \mathrm{ab}$ & 29.57 & 23.67 \\
$4.5 \mathrm{~W}$ & $23.98 \mathrm{a}$ & $21.33 \mathrm{a}$ & $17.77 \mathrm{a}$ & $33.00 \mathrm{a}$ & $34.82 \mathrm{a}$ & 29.31 & 27.26 \\
$\begin{array}{l}\text { BARI Alu-7 } \\
\text { (Diamant) }\end{array}$ & $23.98 \mathrm{a}$ & $17.67 \mathrm{ab}$ & $19.80 \mathrm{a}$ & $27.78 \mathrm{~b}$ & $30.76 \mathrm{ab}$ & 26.53 & 24.34 \\
BARI Alu-8 & $20.96 \mathrm{a}$ & $15.00 \mathrm{ab}$ & $20.10 \mathrm{a}$ & $23.89 \mathrm{bc}$ & $31.86 \mathrm{ab}$ & 26.94 & 23.13 \\
(Cardinal) & & & & & & & \\
\hline CV\% & 14.35 & 16.07 & 0.98 & 7.63 & 13.09 & 12.06 & - \\
\hline
\end{tabular}

Means followed by the same or no letter in the same column do not differ significantly each other at the $5 \%$ level by DMRT.

Table 3. Performances of clonal potato hybrids for tuber yield in RYT at six locations.

\begin{tabular}{|c|c|c|c|c|c|c|c|}
\hline \multirow{2}{*}{$\begin{array}{c}\text { Hybrid } \\
\text { Clone/Variety }\end{array}$} & \multicolumn{7}{|c|}{ Tuber yield (t/ha) at $90 \mathrm{DAP}$} \\
\hline & Joy & Bog & Mun & Jes & Jam & Deb & Mean \\
\hline 4.15 & $30.87 \mathrm{~b}$ & $32.30 \mathrm{c}$ & $\begin{array}{l}32.85 \\
\text { bc }\end{array}$ & 36.48 bc & $45.73 \mathrm{ab}$ & 35.83 & 35.68 \\
\hline $4.26 \mathrm{R}$ & $33.95 \mathrm{ab}$ & $40.28 \mathrm{abc}$ & $\begin{array}{l}32.93 \\
\text { bc }\end{array}$ & $45.78 \mathrm{a}$ & $52.09 \mathrm{a}$ & 46.01 & 41.84 \\
\hline 4.27 & $37.30 \mathrm{a}$ & $36.04 \mathrm{bc}$ & $\begin{array}{l}37.10 \\
a b\end{array}$ & $45.26 \mathrm{a}$ & $48.17 \mathrm{ab}$ & 40.23 & 40.68 \\
\hline 4.40 & $35.24 \mathrm{ab}$ & $43.73 \mathrm{ab}$ & $\begin{array}{l}34.99 \\
\text { bc }\end{array}$ & $36.26 \mathrm{bc}$ & $48.56 \mathrm{ab}$ & 44.69 & 40.58 \\
\hline $4.5 \mathrm{~W}$ & $34.26 \mathrm{ab}$ & $46.41 \mathrm{a}$ & $41.37 \mathrm{a}$ & $41.80 \mathrm{ab}$ & $52.83 \mathrm{a}$ & 47.36 & 44.01 \\
\hline $\begin{array}{l}\text { BARI Alu-7 } \\
\text { (Diamant) }\end{array}$ & $32.58 \mathrm{ab}$ & $38.00 \mathrm{bc}$ & 29.43 c & $33.70 \mathrm{c}$ & $40.65 \mathrm{~b}$ & 39.81 & 35.70 \\
\hline $\begin{array}{l}\text { BARI Alu-8 } \\
\text { (Cardinal) }\end{array}$ & $29.86 \mathrm{ab}$ & $33.68 \mathrm{c}$ & $\begin{array}{l}31.91 \\
\text { bc }\end{array}$ & $32.52 \mathrm{c}$ & $39.97 \mathrm{~b}$ & 40.46 & 34.73 \\
\hline $\mathrm{CV} \%$ & 14.05 & 11.46 & 8.86 & 9.21 & 5.75 & 7.35 & - \\
\hline
\end{tabular}

Means followed by the same or no letter in the same column do not differ significantly each other at the $5 \%$ level by DMRT. 
Table 4 represents the size of the tubers in RYT at Joydebpur. Results showed that the tuber grades by number and weight as expressed in percentage were comparable to the check varieties, which indicated that all the three varieties are acceptable in production of marketable tubers.

Table 4. Grading of tubers of the clonal potato hybrids by number and weight of RYT at 90 DAP.

\begin{tabular}{l|c|c|c|c|c|c}
\hline \multirow{2}{*}{ Variety } & \multicolumn{3}{c|}{ Grading by Number (\%) } & \multicolumn{3}{c}{ Grading by Weight (\%) } \\
\cline { 2 - 7 } & $<28 \mathrm{~mm}$ & $28-55 \mathrm{~mm}$ & $<28 \mathrm{~mm}$ & $<28 \mathrm{~mm}$ & $28-55 \mathrm{~mm}$ & $>55 \mathrm{~mm}$ \\
\hline 4.15 & $12.79 \mathrm{a}$ & $87.02 \mathrm{a}$ & $0.19 \mathrm{~b}$ & $2.08 \mathrm{a}$ & $97.16 \mathrm{a}$ & $0.77 \mathrm{~b}$ \\
$4.26 \mathrm{R}$ & $17.80 \mathrm{a}$ & $82.05 \mathrm{a}$ & $0.15 \mathrm{~b}$ & $2.80 \mathrm{a}$ & $96.29 \mathrm{a}$ & $0.91 \mathrm{~b}$ \\
4.27 & $12.08 \mathrm{a}$ & $86.68 \mathrm{a}$ & $1.23 \mathrm{a}$ & $1.57 \mathrm{a}$ & $93.72 \mathrm{a}$ & $4.71 \mathrm{a}$ \\
4.40 & $14.40 \mathrm{a}$ & $85.10 \mathrm{a}$ & $0.50 \mathrm{~b}$ & $2.07 \mathrm{a}$ & $96.02 \mathrm{a}$ & $1.91 \mathrm{~b}$ \\
$4.5 W$ & $11.44 \mathrm{a}$ & $88.21 \mathrm{a}$ & $0.35 \mathrm{~b}$ & $1.86 \mathrm{a}$ & $96.69 \mathrm{a}$ & $1.45 \mathrm{~b}$ \\
BARI Alu-7 & $16.03 \mathrm{a}$ & $83.20 \mathrm{a}$ & $0.77 \mathrm{ab}$ & $3.32 \mathrm{a}$ & $93.11 \mathrm{a}$ & $3.57 \mathrm{ab}$ \\
(Diamant) & & & & & & \\
BARI Alu-8 & $13.34 \mathrm{a}$ & $89.69 \mathrm{a}$ & $0.31 \mathrm{~b}$ & $2.81 \mathrm{a}$ & $95.87 \mathrm{a}$ & $1.33 \mathrm{~b}$ \\
(Cardinal) & & & & & \\
\hline CV\% & 32.12 & 4.60 & 42.12 & 43.11 & 2.43 & 70.62 \\
\hline
\end{tabular}

Table 5. Yield performances of the clonal hybrids in participatory/on-farm variety trials over locations.

\begin{tabular}{l|c|c|c|c|c|c}
\hline \multirow{2}{*}{$\begin{array}{c}\text { Hybrid } \\
\text { Clone/Variety }\end{array}$} & \multicolumn{6}{c}{ Tuber Yield (t/ha) at 90 DAP } \\
\cline { 2 - 7 } & Mun & Bog & Jess & Jam & Deb & Mean \\
\hline 4.15 & 34.7 & 34.89 & 34.85 & 33.4 & 33.09 & 34.19 \\
$4.26 \mathrm{R}$ & 33.9 & 40.22 & 36.23 & 36.9 & 45.37 & 38.52 \\
4.27 & 32.0 & 27.33 & 33.70 & 35.1 & 36.70 & 32.97 \\
4.40 & 32.7 & 38.77 & 36.08 & 37.4 & 42.69 & 37.53 \\
$4.5 W$ & 31.9 & 38.66 & 39.16 & 39.5 & 45.12 & 38.87 \\
$\begin{array}{l}\text { BARI Alu-7 } \\
\text { (Diamant) }\end{array}$ & 35.3 & 31.99 & 31.96 & 35.6 & 36.81 & 34.33 \\
$\begin{array}{l}\text { BARI Alu-8 } \\
\text { (Cardinal) }\end{array}$ & 33.8 & 27.55 & 32.94 & 30.7 & 40.28 & 33.05 \\
\hline
\end{tabular}

On-farm performance trials showed very good results. All of the three genotypes were top yielders in most of the locations. The average yields were also higher than the other varieties including checks. The mean yields of $4.5 \mathrm{~W}$, 4.26R, and 4.40 were $38.87,38.52$, and $37.53 \mathrm{t} / \mathrm{ha}$, respectively, compared to 33.05 and 34.33 t/ha in checks BARI Alu-8 (Cardinal) and BARI Alu-7 (Diamant), respectively (Table 5). 
Table 6. The identifying characters of three clonal potato hybrids developed by TCRC.

\begin{tabular}{|c|c|c|c|c|}
\hline $\begin{array}{l}\text { Sl. } \\
\text { no. }\end{array}$ & Character & BARI Alu-35 & BARI Alu-36 & BARI Alu-37 \\
\hline 01. & Origin & Bangladesh & Bangladesh & Bangladesh \\
\hline 02. & $\begin{array}{l}\text { Accession } \\
\text { number }\end{array}$ & $4.5 \mathrm{~W}$ & $4.26 \mathrm{R}$ & 4.40 \\
\hline 03. & Parentage & Cardinal X TPS-67 & Patrones X TPS-67 & 934 X TPS-67 \\
\hline 04. & $\begin{array}{l}\text { Plant and } \\
\text { Stem }\end{array}$ & $\begin{array}{l}\text { Medium plant height } \\
\text { with intermediate } \\
\text { type of stem. Stems } \\
\text { are green with weak } \\
\text { extension of } \\
\text { anthocyanine } \\
\text { coloration. }\end{array}$ & $\begin{array}{l}\text { Medium plant height } \\
\text { with intermediate } \\
\text { type of stem. Stems } \\
\text { are green with strong } \\
\text { extension of } \\
\text { anthocyanine } \\
\text { coloration. } \\
\end{array}$ & $\begin{array}{l}\text { Medium plant height } \\
\text { with intermediate } \\
\text { type of stem. Stems } \\
\text { green with no } \\
\text { anthocyanine } \\
\text { coloration. }\end{array}$ \\
\hline 05. & Foliage & $\begin{array}{l}\text { Medium size of leaf } \\
\text { with weak } \\
\text { anthocyanine } \\
\text { coloration of mid } \\
\text { rib. Very weak } \\
\text { waviness of margin } \\
\text { of the leaflet. }\end{array}$ & $\begin{array}{l}\text { Medium size of leaf } \\
\text { with strong } \\
\text { anthocyanine } \\
\text { coloration of mid } \\
\text { rib. Weak waviness } \\
\text { of margin of the } \\
\text { leaflet. }\end{array}$ & $\begin{array}{l}\text { Medium size of leaf } \\
\text { with no } \\
\text { anthocyanine } \\
\text { coloration of mid } \\
\text { rib. Very weak } \\
\text { waviness of margin } \\
\text { of the leaflet }\end{array}$ \\
\hline 06. & Growth habit & Erect & Semi-erect. & Erect \\
\hline \multirow[t]{6}{*}{07.} & $\begin{array}{l}\text { Tubers } \\
\text { Characters }\end{array}$ & & & \\
\hline & Skin Colour & Yellow & Red & Yellow \\
\hline & Shape & Oval & Long oval & Oval to long oval \\
\hline & Depth of eyes & shallow & shallow & shallow \\
\hline & Size & medium & medium to large & medium \\
\hline & Flesh colour & Light cream & Light cream & Light yellow \\
\hline 08. & Sprout & $\begin{array}{l}\text { Sprout size is } \\
\text { medium, broad } \\
\text { cylindrical shape, } \\
\text { red violet, strong } \\
\text { intensity of } \\
\text { anthocyanine } \\
\text { coloration of base, } \\
\text { very strong intensity } \\
\text { of pubescence at the } \\
\text { base }\end{array}$ & $\begin{array}{l}\text { Small, spherical with } \\
\text { pubescence at the } \\
\text { base; weak } \\
\text { anthocyanin } \\
\text { coloration of tip and } \\
\text { pubescence of tip is } \\
\text { absent. }\end{array}$ & $\begin{array}{l}\text { Large, cylindrical, } \\
\text { strong, intensity of } \\
\text { anthocyanin } \\
\text { coloration and } \\
\text { medium to strong } \\
\text { pubescence of the } \\
\text { base. }\end{array}$ \\
\hline 09. & $\begin{array}{l}\text { Duration of } \\
\text { the crop }\end{array}$ & 90 to 95 days & 90 to 95 days & 90 to 95 days \\
\hline 10. & Yield range & 30-45 (t/ha) & 32-45 (t/ha) & 30-45 (t/ha) \\
\hline
\end{tabular}


Table 7. Pictorial presentation of some identifying characters of the three clonal potato hybrids developed by TCRC.

\begin{tabular}{|c|c|c|c|c|}
\hline $\begin{array}{l}\text { Sl. } \\
\text { no. }\end{array}$ & Character & BARI Alu-35 (4.5W) & BARI Alu-36 (4.26R) & BARI Alu-37 (4.40) \\
\hline 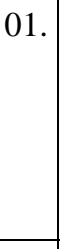 & Foliage & 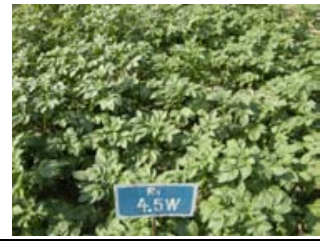 & 3.1. & 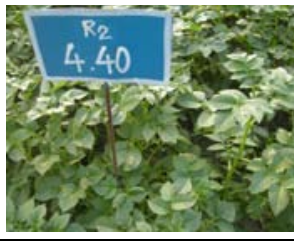 \\
\hline 02. & $\begin{array}{l}\text { Plant and } \\
\text { Stem }\end{array}$ & & & \\
\hline 03. & Leaves & & & T \\
\hline . & $\begin{array}{l}\text { Tubers } \\
\text { with } \\
\text { cross } \\
\text { section } \\
\text { (Flesh } \\
\text { colour) } \\
\end{array}$ & {$[\cdots$} & $\ldots$ & L.... \\
\hline 05. & Sprout & & & \\
\hline
\end{tabular}

These three varieties 4.5W, 4.26R, and 4.40 were released by NSB in 2012 as BARI Alu-35, BARI Alu-36, and BARI Alu-37. The identifying characters of the three varieties are presented in Table 6 and 7.

\section{References}

TCRC. 2001-2010. Annual Reports of the TCRC for the years from 2001-02 to 2010-11. TCRC, BARI, Joydebpur, Gazipur, Bangladesh. 
TCRC. 2012. Annual Reports of the TCRC for the year 2011-12. TCRC, BARI, Joydebpur, Gazipur, Bangladesh.

Clarke, A. F. and P. M. Lombard. 1939. Relation of length of day to flower and seed production in potato varieties. Am. Potato J. 16: 236-244.

Kundu, B. C. and K. H. Kabir. 2012. Potato introduction of potato varieties for processing. In "Proc. Wrksp. Potato Processing in Bangladesh". Hussain, M. M. et al. (eds.). TCRC and AFE, Dhaka. P. 29-38.

Patterson, G. F. 1953. A method of obtaining fruits in the potato variety Russet Burbank. Am. Potato J. 30: 89-91.

Rashid, M. M., M. H. Rashid and M. H. Sarker. 1987. Yield potentials of exotic potato varieties in Bangladesh. PRC, BARI, Joydebpur, Gazipur. 62 P.

Rashid, M. H., M. H. Kabir and M. M. Rashid. 1990. Response of different genotypes of potatoes to manipulated photoperiod. J. Indian Potato Assoc. (JIPA). 17: 149-151

Rashid, M. H. 1993. TPS research in Bangladesh: Past activities and future prospects. TCRC, BARI, Joydebpur, Gazipur. 98 P.

Rashid, M. H., M. H. Kabir and M. M. Rashid. 1993. Effect of some flower inducing techniques on true potato seed production in Bangladesh. Asian Potato J. 3: 9-10

Rashid, M. H. 2004. Variety development of potato. In "Seed Potato Production". Seed Industry Development, Seed Wing, MOA/DANIDA Project. Khamarbari, Dhaka. P. 2-17.

Rasul, M. G., M. S. Nahar. M. H. Rashid and M. M. Rashid. 1994. Response of different potato genotypes to artificial photoperiod under short day condition. Bangladesh J. Sci. Res. 12(2): 227-231

Rashid, M. H. and M. A. Hoque. 2009. Potato variety development strategy in Bangladesh. Proceedings of the international conferance on Plant Breeding and Seed for Food Security. BPBGSB, SBAU, Sher-e-Bangla Nagar, Dhaka-1207.

Thijn, G. A. 1954. Observations on flower induction with potatoes. Euphytica 3: 28-34.

Zafar, M. A. 1955. Application of certain hormones to prevent floral abscission in two potato (S. tuberosum) varieties. Am. Potato J. 32: 283-292. 